\title{
Good Government Governance in The Internal Control System and Audit Opinion
}

\author{
Agus Bandiyono \\ Politeknik Keuangan Negara STAN \\ Email Address: \\ agusbandiyono@pknstan.ac.id
}

\begin{abstract}
This study wants to describe the impact of the implementation of the internal control system in the Governance of local governance to the audit opinion CPCs local governments achieved with the application of the principles of good government governance as a moderator variable. This study is a descriptive quantitative study that seeks to describe an application of an internal control system to BPK's audit opinion by applying the principles of good government governance as a moderating variable. Respondents in this study were OPD-OPDs in the Banten Province government, Pandeglang Regency Government, and Serang City Government. The data used in the analysis of this research is data that comes from a questionnaire which is then filled in by the respondent. SEM PLS is used as a tool to analyze the data in this study. The results of this study indicate that the implementation of a good internal control system can have a positive and significant impact on the audit opinion of BPK RI. The moderator variable in the application of the principles of good governance is also able to act as a moderating variable, namely being able to increase a positive and significant impact on the Audit Opinion Raihan BPK.
\end{abstract}

Keywords: auditing, internal control system, good government governance, public sector accounting, state finances.

Abstrak: Studi ini ingin menggambarkan dampak dari penerapan system pengendalian intern dalam tata Kelola pemerintahan daerah terhadap opini audit BPK yang pemerintah daerah raih dengan penerapan prinsip-prinsip good government governance sebagai variabel moderator. Studi ini adalah studi kuantitaif deskriptif yang ingin mencari gambaran dari sebuah penerapan system pengendalian intern terhadap opini audit BPK dengan penerapan prinsip-prinsip good government governance sebagai variabel moderator. Responden dalam penelitian ini adalah OPD-OPD yang ada di wilayah pemerintah Provinsi Banten, Pemerintah Kabupaten Pandeglang dan Pemerintah Kota Serang. Data yang digunakan dalam analisis penelitian ini adalah data yang berasal dari angket yang kemudian di isi oleh responden. SEM PLS digunakan sebagai alat bantu menganalisis data dalam penelitian ini. Hasil penelitian ini menunjukkan bahwa penerapan system pengendalian intern yang baik mampu berdampak positif dan signifikan terhadap Raihan opini audit BPK RI. Variabel moderator penerapan prinsip-prinsip good governance juga mampu berperan sebagai variabel moderator yaitu mampu meningkatkan dampat yang positif dan signifikan terhadap Raihan Opini Audit BPK.

Kata kunci: auditing, system pengendalian internal, good government governance, akuntansi sector public, keuangan Negara. 


\section{INTRODUCTION}

One manifestation of the responsibility of local governments in their regional management activities is the collection of audit opinions from the Supreme Audit Agency of the Republic of Indonesia. Local governments that get unqualified audit opinions from the BPK have better financial performance than local governments that get fair with exceptions audit opinions, let alone without giving an opinion. The audit opinion is one of the benchmarks for local governments in managing their regional finances for the welfare of their people, although audit opinion is not a measure of the level of corruption in a region.

Based on the Summary of Financial Audit Results Semester I of 2020 for regional government financial reports, it is stated that 10,499 problems are consisting of 5,175 cases of weakness in the internal control system and 5,324 cases of non-compliance with statutory regulations. The results of the BPK RI Audit for a semester I of 2020 on 541 Regional Government financial reports found 5,175 cases of weaknesses in the Internal Control System, which consisted of 1,729 or 33\% of cases of accounting and reporting control systems. Weaknesses of the accounting and reporting Control System for the 2019 Regional Government Financial Statements recorded 518 local governments, consisting of 916 cases because 473 local governments had not recorded the report, the report preparation process was not following the provisions that occurred in 300 local governments, and 223 cases. Local governments are caused by delays in reporting, SIA and reporting, SIA and reporting that have not been supported by adequate human resources.

Weaknesses of the budget and expenditure implementation control system totaling 2,338 consisting of inadequate planning of activities occurred in 407 local governments (629 cases), deviations from regulations occurred in 393 local governments (741 cases) and 404 cases of local government occurred due to inappropriate revenue management., the implementation of the policy was not appropriate, the implementation of the policy was 968 cases.

Weaknesses in internal control structures occurred in 426 local governments $(1,108$ cases) consisting of incomplete Standard Operating Procedures, which occurred in 267 local governments (461 cases), Standard Operating Procedures that were not adhered to occurred in 301 local governments (475 cases), and monitoring units. internal government has not yet occurred in 120 local governments (172 cases).

Table 1. Group of Findings Weaknesses of the Control System on the Results of the Audit of Regional Government Financial Statements for 2018-2020

\begin{tabular}{c|l|c|c|c}
\hline No & \multicolumn{1}{|c|}{ Group of Findings } & $\begin{array}{c}\text { Number of } \\
\text { cases } \\
\mathbf{2 0 1 8}\end{array}$ & $\begin{array}{c}\text { Number of } \\
\text { cases } \\
\mathbf{2 0 1 9}\end{array}$ & $\begin{array}{c}\text { Number of } \\
\text { cases } \\
\mathbf{2 0 2 0}\end{array}$ \\
\hline 1 & $\begin{array}{l}\text { Weaknesses of Accounting and } \\
\text { Reporting Control Systems }\end{array}$ & 2,083 & 1,826 & 1,729 \\
\hline 2 & $\begin{array}{l}\text { Weaknesses of the Control } \\
\text { System for the Implementation of } \\
\text { the Expenditure Budget }\end{array}$ & 2,887 & 2,753 & 2,338 \\
\hline 3 & $\begin{array}{l}\text { Weaknesses of Internal Control } \\
\text { Structure }\end{array}$ & 1,252 & 1,279 & 1,108 \\
\hline Total & 6,222 & 5,858 & 5,175 \\
\hline
\end{tabular}

Source: IHPS BPK RI semester 1 of 2020 
Weaknesses of the internal control system in local governments generally occur because (BPK, 2020), namely: 1) responsible officials have not been optimal in conducting coaching and supervision, 2) has not updated the application for recording and reporting, 3) the local government has not set and perfected accounting policies, 4) The regional government budget team is not accurate enough, 5) The responsible official has not carried out the supervision, 6) The official has not compiled SOP, 7) Local government has not made recommendations from the BPK.

With the development of audit opinion on local government financial reports in the last 5 years (2015-2019), audit opinion on regional government financial reports has improved. During the 2015-2019 period, local governments that received unqualified audit opinions increased by $32 \%$, that is, $58 \%$ of unqualified audit opinions in 2015 rose to $90 \%$ in 2019. Of the 541 local government financial reports $90 \%$ or 485 reports Local government finances to get an unqualified opinion, $9 \%$ or 50 local government reports get a qualified opinion and $1 \%$ or 6 local government financial reports get an opinion without giving an opinion.

The development of audit opinion Banten provincial government report in 2015-2019 can be seen in Table 2 below:

Table 2. Development of Audit Opinion Banten province (Years 2015-2019)

\begin{tabular}{c|l|l|l|l|l|l}
\hline \multirow{2}{*}{ No. } & \multicolumn{5}{|c}{} \\
\cline { 3 - 7 } & & 2015 & 2016 & 2017 & 2018 & 2019 \\
\hline 1 & Banten Province & WDP & WTP & WTP & WTP & WTP \\
\hline 2 & Lebak & WTP & WTP & WTP & WTP & WTP \\
\hline 3 & Pandeglang & WDP & WTP & WTP & WTP & WTP \\
\hline 4 & Serang District & WTP & WTP & WTP & WTP & WTP \\
\hline 5 & Tangerang District & WTP & WTP & WTP & WTP & WTP \\
\hline 6 & Cilegon & WTP & WTP & WTP & WTP & WTP \\
\hline 7 & Serang & WDP & WDP & WTP & WTP & WTP \\
\hline 8 & Tangerang City & WTP & WTP & WTP & WTP & WTP \\
\hline 9 & Kota Tangerang Selatan & WTP & WTP & WTP & WTP & WTP \\
\hline Source IHPS semester 1 of 2020 & & & &
\end{tabular}

Source: IHPS semester 1 of 2020

Based on Law Number 15 of 2004 concerning the examination of the management and accountability of state finances, the Indonesian Republican Audit Agency in providing an audit opinion must contain several criteria, namely; regarding the effectiveness of the internal control system and compliance with laws \& regulations.

The results of the audit opinion by the Supreme Audit Agency (BPK) are used or used as the basis for further policy-making by the Regional Government. In general, users of audit opinion results from the Supreme Audit Agency are divided into two (Rante, 2018), namely: 1) External parties and 2) Internal parties. External parties, namely the public, use audit reports from the Supreme Audit Agency to identify and assess the performance of local governments, especially regarding the accountability of financial reports, and to measure public confidence in their local governments. Another external party, namely the auditor, in this case, is the Supreme Audit Agency, which makes audit opinion a form of professionalism and is mandated by law. Users of audit opinion by the Audit Agency from internal parties are government entities themselves, local governments use the results of audit opinions as a form of imaging to the public. 
Reform of state finances in Indonesia, marked by the issuance of a package of laws on state finance in 2003 and 2004 mandated the importance of good financial governance, as well as the application of international best practices adapted to conditions in Indonesia. State finance reform includes reforms in the areas of government financial accounting and reporting. This is marked by the obligation to prepare a state financial accountability report in the form of a government financial report which at least consists of budget realization reports, balance sheets, cash flow reports, and notes on financial statements attached with financial statements of state companies and other agencies (Marwanto et al., 2014).

Good regional financial governance according to government regulation number 12 of 2019 article 1 paragraph 2, namely regional financial management is all activities that include planning, budgeting, implementation, administration, reporting, accountability, and supervision of regional finances. Meanwhile, according to the regulation of the Minister of Home Affairs of the Republic of Indonesia Number 19 of 2020 concerning regional financial management index measurement, the regional financial management index is measured through six dimensions, namely; 1) suitability of planning and budgeting documents, 2) budget allocation in APBD, 3) transparency of regional financial management, 4) budget absorption, 5) regional financial condition, 6) opinion of the financial audit agency on regional government financial reports. The audit opinion is one of the benchmarks for the success of local governments in managing regional finances for the welfare of their people.

According to (Sedarmayanti, 2012) stakeholders of good governance can be grouped into three, namely; Government. The role of the government in realizing good governance is to play a role in providing facilities for the interaction of activities so that if there is fraud or irregularities it can be immediately resolved. The private. The sector plays an active role in the interaction between various informal sectors in society. Civil society. Society interacts in various fields of life, interaction in the social, economic, political, and educational fields which serves as a bridge between government and individuals.

Based on the corruption perception index score, Indonesia continues to experience improvement from year to year. In 2020, according to (Transparency International Indonesia, 2020), the corruption index in Indonesia has improved, which is in position 85 out of 180 countries, while in ASEAN Indonesia ranks fourth after Singapore, Brunei Darussalam, Malaysia.

Based on data from the Corruption Eradication Commission (KPK) from 2004-2019, Banten province was ranked in the top 10 provinces with the most cases of corruption, namely 24 cases. The provincial government has received an unqualified opinion from 2016 until now, meaning that the BPK audit opinion does not reflect a good corruption perception index either.

\section{THEORETICAL REVIEW}

Internal Control Systems. According to (COSO, 2013) the internal control system is an activity carried out by commissioners, management, and other personnel, which is formed to provide adequate confidence about the achievement of three objectives, namely the effectiveness and efficiency of operations, reliability of financial reporting, compliance against applicable laws and regulations. According to the Government Regulation of the Republic of Indonesia, Number 60 of 2008 concerning the government internal control 
system is an integral process of actions and activities carried out continuously by the leadership and all employees to provide adequate confidence in the achievement of organizational goals through effective and efficient activities, reliability. financial reporting, safeguarding state assets, and compliance with laws and regulations. Meanwhile, internal supervision, namely the entire process of audit, review, evaluation, monitoring, and other supervisory activities on the implementation of organizational duties and functions to provide adequate assurance that activities have been carried out following established benchmarks effectively and efficiently for the benefit of the leadership in realizing good governance.

Elements of the government internal control system according to government regulation number 60 of 2008 consist of the following elements:

Control environment The control. the environment in a government agency requires agency leaders to create and maintain a controlled environment that can lead to positive and conducive behavior for the application of an internal control system in their work environment, through 1) upholding the integrity and ethical values; 2). commitment to competence; 3). conducive leadership; 4). formation of an organizational structure following the needs; 5). appropriate delegation of powers and responsibilities; 6). formulating and implementing sound policies on human resource development; 7). an embodiment of the role of an effective government internal control apparatus; and 8). good working relationship with related government agencies.

Risk Assessment. Leaders of Government Agencies are required to carry out risk assessments. The risk assessment in question consists of 1). risk identification; and 2). risk analysis. In the framework of risk assessment, the leadership of Government Agencies determines 1) the objectives of Government Agencies; and 2). objectives at the activity level, guided by the statutory regulations

Control Activities The Leaders of Government Agencies are required to carry out control activities following the size, complexity, and nature of the duties and functions of the Government Agencies concerned. The implementation of control activities at least has the following characteristics: 1). control activities are prioritized on the main activities of Government Agencies; 2). control activities must be linked to the risk assessment process; 3 ). the selected control activities are adjusted to the special characteristics of the Government Agencies; 4). policies and procedures must be established in writing; 5). established procedures must be carried out following those stipulated in writing, and 6). control activities are evaluated regularly to ensure that they are still appropriate and functioning as expected.

Information and Communication. Leaders of Government Agencies are required to identify, record, and communicate information in an appropriate form and time. Communication of information must be carried out effectively. To carry out effective communication, the leadership of Government Agencies must at least: 1). provide and utilize various forms and means of communication, and 2). manage, develop, and update information systems continuously.

Internal Control Monitoring. Heads of Government Agencies are required to monitor the Internal Control System. Internal Control System monitoring is carried out through continuous monitoring, separate evaluations, and follow-up recommendations on audit results and other reviews. Continuous monitoring is carried out through routine management 
activities, supervision, comparison, reconciliation, and other actions related to the implementation of tasks. A separate evaluation is conducted through self-assessment, review, and testing of the effectiveness of the Internal Control System. A separate evaluation can be carried out by the government internal supervisory apparatus or government external parties. A separate evaluation can be carried out using the internal control test list.

Audit. Opinion The audit opinion of the Supreme Audit Agency of the Republic of Indonesia is a professional auditor's statement regarding the fairness of the financial statements presented based on criteria of conformity with government accounting standards, adequacy of disclosure, compliance with laws and regulations, and the effectiveness of the internal control system.

Based on Law Number 15 of 20014, there are four types of opinions given by the Supreme Audit Agency of the Republic of Indonesia on government financial reports, namely:

Unqualified audit opinion. To declare that the audited entity's financial statements present fairly in all material respects, the position The financial statements, results of operations, and cash flows of certain entities following generally accepted accounting principles in Indonesia.

Unqualified audit opinion. State that the audited entity's financial statements present fairly in all material respects, financial position, results of operations, and cash flows of the entity. following generally accepted accounting principles in Indonesia, except for the impact of matters relating to the excluded.

Unfair audit opinion. State that the audited entity's financial statements do not fairly present the financial position, results of operations, and cash flows of a particular entity following generally accepted accounting principles in Indonesia.

Audit Opinion Does Not Give Opinion. State that the Auditor does not express an opinion on the report if the scope of the audit performed is not sufficient to form an opinion.

Good Government Governance. In 1997, UNDPformulated 9 principles of good governance that must be upheld to implement good governance.

Participation. Every person or community member, male and female, has the same voting rights in the decision-making process either directly or through representative institutions, according to their respective interests and aspirations.

Law Enforcement (Rule of Law). The legal and statutory framework must be just, upheld, and obeyed in its entirety, especially the rule of law regarding human rights.

Transparency (Transparency). Transparency must be built in the framework of the free flow of information.

Responsiveness (Responsiveness). Every institution and its processes must be directed at efforts to serve various interested parties (stakeholders).

Consensus Oriented (Consensus Orientation) Good. The government will act as an intermediary for different interests to reach a consensus or the best opportunity for the interests of each party and if possible can also be applied to various policies and procedures to be determined by the government.

Justice / Equity (Equity). Good governance will provide both men and women with opportunities in their efforts to improve and maintain their quality of life. 
Effectiveness and efficiency (Effectiveness \& Efficiency). Every activity and the institutional process is directed to produce something according to the need through the best possible use of the various available sources.

Accountability (Accountability). Decision-makers in public sector organizations, private and civil society have accountability (accountability) to the general public as well as to the owners.

Strategic Vision. Leaders and society have a broad and long-term perspective on good governance and human development at the same time they need for development is felt.

According to BPK (Nofianti, 2015), the three main pillars of good governance are (1) transparency, (2) accountability, (3) participation.

Transparency. Transparency is a principle that guarantees access or freedom for everyone to obtain information about government administration, namely information about policies, the process of making and implementing them, and the results achieved. Transparency, namely the existence of an open policy for supervision. Information is information about every aspect of government policy that is accessible to the public. (Bandiyono, 2019).

The principles of transparency can be measured through several indicators (Krina, 2003) as follows: 1. A mechanism that ensures openness and standardization of all public service processes. 2. Mechanisms that facilitate public inquiries about various public policies and services, as well as processes within the public sector. 3. Mechanisms that facilitate reporting and dissemination of information as well as misconduct by public officials in serving activities

Accountability. In implementing accountability within government agencies (LAN-RI, 2000) it is necessary to pay attention to the following principles: 1 . There must be a commitment from the leadership and all staff agencies to carry out the management of mission implementation to be accountable 2. Must be a system that can ensure the consistent use of resources with the prevailing laws and regulations 3 . Must be able to show the level of achievement of the goals and objectives that have been set. 4. Must be oriented towards achieving the mission and mission as well as the results and benefits obtained. 5. Must be honest, objective, transparent, and innovative as a catalyst for change in management of government agencies in the form of updating performance measurement methods and techniques and preparing accountability reports.

Participation. Principles and indicators of public participation in budgeting according to Sulistioni and Hendriadi (2004) include the following: (1) Access to active public participation in the process of program formulation and budget decision making. The indicators are as follows: a. In the budget preparation process, space is opened for direct public involvement. B. In the legislative process, what are the frequency of the public hearings, and which parties are involved in these activities? The percentage can be measured by comparing the number of sessions officially scheduled with the number of public hearings held in the Regional Government. (2) There is a regulation that provides a place for control by independent institutions and the community, both individually and institutionally as a medium for checks and balances a. The existence of regulations that become the legal basis and explain the limits of the authority and responsibility of an independent control institution or the public in conducting supervision and monitoring of the implementation of state finances $b$. The substance of the regulations provides space for independent institutions or the public to access state financial documents c. How many 
control institutions and other elements of society pay attention to the process of managing state finances. (3) There is a proactive attitude of local governments to encourage citizen participation in the budgeting process. This is due to the sharp gap between public awareness of how to participate effectively and the aspirations of realizing an aspirational APBD.

The Effect of Internal Control System Implementation on Audit Opinion. Research (Safitri and Darsono, 2015) concluded that the internal control system variable had a positive but insignificant effect at the 0.05 significance level on BPK's audit opinion on local governments. Research by (Zufaldin and Maulina, 2017) states that the audit opinion on the financial statements of the Lhokseumawe city government based on the internal control system still needs special handling because there are allegedly many abuses and abuse of authority. (Irman and Suryati, 2017) state that the results of hypothesis testing indicate that the weakness of the internal control system affects the acceptance of audit opinion. The weaknesses of SPI are considered to harm the acceptance of Audit opinion, which means that the greater the SPI weaknesses found, the less likely the local government financial reports will accept the WTP opinion. Weaknesses of SPI include not recording / not being done or inaccurate, the report preparation process is not following the provisions, the entity is late in submitting reports, inadequate accounting and reporting information systems, and accounting and reporting information systems not supported by adequate human resources. (Winarto, 2020) in the research that has been conducted, obtained partial hypothesis testing results (t-test) of internal control, it can be concluded that partially internal control has a significant effect on audit opinion. This shows that auditors who have good internal control will easily provide their audit opinion. From the results of partial hypothesis testing (t-test) of audit evidence, it can be concluded that partially audit evidence has a significant effect on audit opinion. This shows that auditors who have audit evidence following their standards can provide a better audit opinion. The simultaneous hypothesis testing ( $F$ test) shows that internal control and audit evidence together have a significant effect on audit opinion. The better the level of internal control and audit evidence that the auditor has, the better the audit opinion will be.

Based on some previous research, an initial hypothesis can be drawn that the application of the internal control system affects the audit opinion.

H1: The application of the Internal Control System affects the Audit Opinion.

The effect of the Internal Control System Application on the Audit Opinion by the Application of the Principles of Good Government Governance as a Moderator Variable The research conducted by (Azlina and Amelia, 2014) shows that the variable good governance affects the performance of the Pelalawan regional government significantly. (Agung and Mulyani's, 2020) shows that good governance has a positive and significant impact on the quality of financial reports, (Sari and Tamrin, 2020) find evidence that shows that there is a significant influence between the implementation of good government governance on the quality of financial statement information in the Agency. Regional Financial and Asset Manager Kendari City. This is in line with the results of interviews that researchers have conducted. Where the Regional Financial and Asset Management Agency of Kendari City has implemented the principles of Good Government Governance. 
Based on some of the research above, an initial hypothesis can be drawn that the application of the internal control system affects audit opinion by applying the principles of good government governance as a moderator variable.

H2: The application of the Internal Control System affects the Audit Opinion by applying the principles of Good Government Governance as a variable moderator.

Based on several previous studies used as a reference in this study, the research framework is as follows:

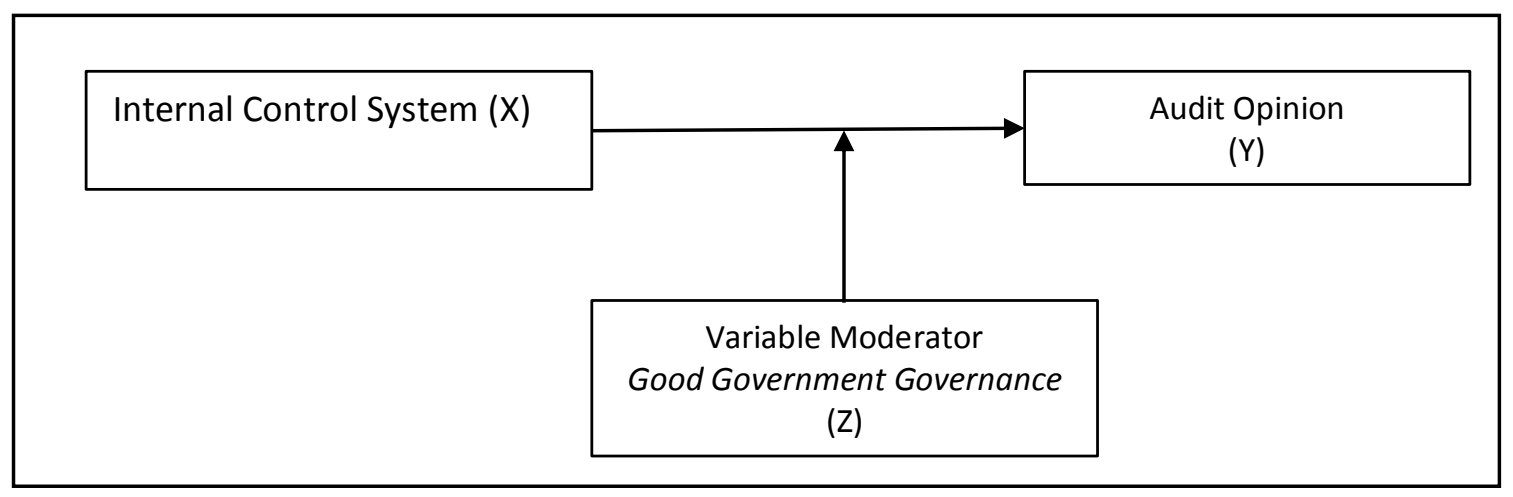

Figure 1. Framework

Hypothesis. Based on the literature review and the framework above, the hypothesis of this study is:

\begin{tabular}{|l|l|l|}
\hline H1 & $:$ & $\begin{array}{l}\text { The application of the Internal Control System affects the Audit Opinion of the } \\
\text { BPK }\end{array}$ \\
\hline H2 & $:$ & $\begin{array}{l}\text { Implementation of the Internal Control System influencing the BPK Audit Opinion } \\
\text { by applying the principles of good government governance as a moderator variable }\end{array}$ \\
\hline
\end{tabular}

\section{METHODS}

Sample and Data Collection. The population in this study were all OPDs in the ProGovernment area. vinsi Banten, Pandeglang Regency and Serang City. The sample in the study was all DPOs that met the research criteria, namely, excluding public and sub-district services. Data were collected by distributing questionnaires to OPDs who were the research samples and using a literature study, namely looking at the results of BPK audits of the Banten Provincial Government, Pandeglang Regency, and Serang City.

Measurement of Variable. Variables in research are measured using ordinal and nominal scales. The data obtained from the questionnaire results are in ordinal form, while the data from the BPK audit results are in nominal form.

Regression Analysis Regression. the analysis aims to determine the estimated value of the population mean or the average value of the research variables. The data that has been 
collected will be analyzed using statistical analysis tools, namely Regression Analysis, the formula is:

$$
\mathbf{Y}=\alpha+\boldsymbol{\beta}_{1} \mathbf{X}_{1}+\boldsymbol{\beta}_{2} \mathbf{X}_{2}+\mathbf{e}
$$

Data Analysis The data collected in this study will be used as a basis for answering a hypothesis that is determined. The tool for processing the collected data is SEM PLS.

DescriptiveTest. Based on the questionnaire that has been collected, next is to know the level of the respondent's tendency in answering questions/statements regarding the application of the internal control system and the application of the principles of good government governance. The criteria for the range of values are presented in the following table:

Table 3. Value Range and Categorization

\begin{tabular}{c|c|l}
\hline No & Value Range & \multicolumn{1}{c}{ Category } \\
\hline 1 & $1.00-1.80$ & Very Less \\
\hline 2 & $1.81-2.60$ & Less \\
\hline 3 & $2.61-3.40$ & Medium \\
\hline 4 & $3.41-4.20$ & High \\
\hline 5 & $4.21-5.00$ & Very High \\
\hline
\end{tabular}

Variable Description of Control System Implementation Intern. The variable of internal control system implementation has five dimensions and 26 indicators. Based on the predetermined value ranges and categorization, the value of each indicator can be seen as in table 4 below:

Table 4. Average Value and categorization of VariableImplementation of Internal Control Systems

\begin{tabular}{c|c|c|c}
\hline No & Indicator & Mean & Category \\
\hline $\mathbf{1}$ & X.1 & 4.20 & High \\
\hline $\mathbf{2}$ & X.2 & 4.46 & Very High \\
\hline $\mathbf{3}$ & X.3 & 4.48 & Very High \\
\hline $\mathbf{4}$ & X.4 & 4.42 & Very High \\
\hline $\mathbf{5}$ & X.5 & 4.90 & Very High \\
\hline $\mathbf{6}$ & X.6 & 4.70 & Very High \\
\hline $\mathbf{7}$ & X.7 & 4.26 & High \\
\hline $\mathbf{8}$ & X.8 & 4.10 & High \\
\hline $\mathbf{9}$ & X.9 & 4.12 & High \\
\hline $\mathbf{1 0}$ & X.10 & 4.18 & Very High \\
\hline $\mathbf{1 1}$ & X.11 & 4.41 & Very High High \\
\hline $\mathbf{1 2}$ & X.12 & 4.49 & High \\
\hline $\mathbf{1 3}$ & X.13 & 4.48 & \\
\hline $\mathbf{1 4}$ & X.14 & 3.96 & \\
\hline
\end{tabular}




\begin{tabular}{c|c|c|c}
\hline $\mathbf{1 5}$ & X.15 & 4.50 & Very High \\
\hline $\mathbf{1 6}$ & X.16 & 4.14 & High \\
\hline $\mathbf{1 7}$ & X.17 & 4.16 & High \\
\hline $\mathbf{1 8}$ & X.18 & 4.52 & Very High \\
\hline $\mathbf{1 9}$ & X.19 & 4.18 & High \\
\hline $\mathbf{2 0}$ & X.20 & 4.12 & High \\
\hline $\mathbf{2 1}$ & X.21 & 4.16 & High \\
\hline $\mathbf{2 2}$ & X.22 & 4.18 & Very High \\
\hline $\mathbf{2 3}$ & X.23 & 4.40 & High \\
\hline $\mathbf{2 4}$ & X.24 & 4.17 & High \\
\hline $\mathbf{2 5}$ & X.25 & 3.91 & Very High \\
\hline $\mathbf{2 6}$ & X.26 & 4.41 & \\
\hline & Average & 4.31 & \\
\hline
\end{tabular}

Table 5. Average Value and Categorization of Research Dimensions Variable Application of Internal Control Systems

\begin{tabular}{c|c|c|c}
\hline No & Dimensions & Mean & Ka category \\
\hline 1 & Control Environment & 4.44 & Very High \\
\hline 2 & Risk Assessment & 4.15 & High \\
\hline 3 & Control Activities & 4.28 & Very High \\
\hline 4 & Information and Communication & 4.29 & Very High \\
\hline 5 & Monitoring & 4.16 & High \\
\hline & Average Score & 4.31 & Very High \\
\hline
\end{tabular}

Of the five dimensions of the variable implementation of the control system, 2 dimensions still need to be improved again, namely the dimensions of risk assessment and monitoring, each of which falls into the high category.

Variable Description of Application of the Principles of Good Government Governance. The variable of applying the principles of good government governance has three dimensions, namely transparency, participation, and accountability. Each dimension has its indicator. Based on the value range and categorization table above, each indicator and dimension value for the research variable of the application of the principles of good government governance can be seen in table 6 and table 7 below. 
Table 6. Average Value and Categorization of Research Indicators Variable Application of the Principles of Good Government Governance

\begin{tabular}{c|c|c|c}
\hline No & Indicator & Mean & Category \\
\hline $\mathbf{1}$ & Z.1 & 4.37 & Very High \\
\hline $\mathbf{2}$ & Z.2 & 4.42 & Very High \\
\hline $\mathbf{3}$ & $\mathrm{Z} .3$ & 3.98 & High \\
\hline $\mathbf{4}$ & $\mathrm{Z} .4$ & 4.18 & High \\
\hline $\mathbf{5}$ & $\mathrm{Z} \mathrm{.5}$ & 4.10 & High \\
\hline $\mathbf{6}$ & $\mathrm{Z} .6$ & 4.24 & Very High \\
\hline $\mathbf{7}$ & $\mathrm{Z} .7$ & 3.85 & High \\
\hline $\mathbf{8}$ & Z.8 & 4.02 & High \\
\hline $\mathbf{9}$ & Z.9 & 4.10 & Very High \\
\hline $\mathbf{1 0}$ & Z.10 & 4.88 & \\
\hline
\end{tabular}

Table 7. Average Value and Categorization of Research Dimensions Variable Implementation of the Principles of Good Government Governance

\begin{tabular}{c|c|c|c}
\hline No & Dimension & Mean & Category \\
\hline 1 & Transparency & 4.26 & Very High \\
\hline 2 & Participation & 4.09 & High \\
\hline 3 & Accountability & 4.33 & Very High \\
\hline & & $\mathbf{4 . 2 1}$ & Very High \\
\hline
\end{tabular}

Validity test. A statement/research variable is declared valid if it has a loading factor above 0.70 against the intended construct. While the loading factor of 0.50 to 0.60 can still be maintained (Ghozali, 2014). The results of the validity test can be seen in Table 8 below. 
Table 8. Validity Test

\begin{tabular}{|c|c|c|c|c|}
\hline No. & Variable & Indicator & Loading Factor & Description \\
\hline 1 & \multirow{26}{*}{$\begin{array}{l}\text { Internal Control } \\
\text { System }\end{array}$} & X.1 & 0862 & Invalid \\
\hline 2 & & X.2 & 0761 & Valid \\
\hline 3 & & X.3 & 0973 & Valid \\
\hline 4 & & X.4 & 0884 & Invalid \\
\hline 5 & & X.5 & 0.922 & Invalid \\
\hline 6 & & X.6 & 0.957 & Valid \\
\hline 7 & & X. 7 & 0.876 & Valid \\
\hline 8 & & $\mathrm{X} .8$ & 0.985 & Valid \\
\hline 9 & & X.9 & 0.684 & Valid \\
\hline 10 & & $\mathrm{X} .10$ & 0.912 & Valid \\
\hline 11 & & X.11 & 0.845 & Valid \\
\hline 12 & & X.12 & 0.742 & Valid \\
\hline 13 & & X.13 & 0.846 & Valid \\
\hline 14 & & X.14 & 0.816 & Valid \\
\hline 15 & & $\mathrm{X} .15$ & 0.906 & valid \\
\hline 16 & & X.16 & 0696 & invalid \\
\hline 17 & & $\mathrm{X} .17$ & 0714 & valid \\
\hline 18 & & X.18 & 0824 & valid \\
\hline 19 & & X.19 & 0936 & valid \\
\hline 20 & & X.20 & 0813 & valid \\
\hline 21 & & X.21 & 0962 & valid \\
\hline 22 & & X.22 & 0837 & valid \\
\hline 23 & & X.23 & 0819 & valid \\
\hline 24 & & X.24 & 0679 & Valid \\
\hline 25 & & X.25 & 0815 & Valid \\
\hline 26 & & X.26 & 0729 & Valid \\
\hline 27 & \multirow{7}{*}{$\begin{array}{l}\text { Principles of } \\
\text { Good } \\
\text { Government } \\
\text { Governance }\end{array}$} & Z.1 & 0817 & Valid \\
\hline 28 & & Z.2 & 0887 & Valid \\
\hline 29 & & Z.3 & 0991 & Valid \\
\hline 30 & & Z.4 & 0688 & Valid \\
\hline 31 & & Z. 5 & 0.819 & Valid \\
\hline 32 & & Z.6 & 0.961 & Valid \\
\hline 33 & & Z.7 & 0.672 & Valid \\
\hline
\end{tabular}




\begin{tabular}{l|l|l|l|l}
\hline $\mathbf{3 4}$ & \multirow{2}{*}{$\mathbf{3 5}$} & Z.8 & 0.962 & Valid \\
\cline { 3 - 5 } & $\mathbf{3 6}$ & Z.9 & 0.918 & Valid \\
\cline { 3 - 5 } & Z.10 & 0.882 & Valid \\
\hline
\end{tabular}

Reliability test. The construct is said to be reliable if the values are composite reliability and Cronbach alpha above 0.70 . Test Reliability can be seen in the following table:

Table 9. Reliability Test

\begin{tabular}{l|c|c}
\hline & Cronbach's Alpha & Composite reliability \\
\hline Audit Opinion & 0885 & 0898 \\
\hline $\begin{array}{l}\text { Application of the Principles of Good Government } \\
\text { Governance }\end{array}$ & 0876 & 0843 \\
\hline Implementation of Internal Control Systems & 0887 & 0901 \\
\hline
\end{tabular}

Hypothesis Testing. Effect of Implementation of Internal Control System Against Audit opinion.

Table 10. R Square

\begin{tabular}{|c|c|c|}
\hline & R Square & R Square Adjusted \\
\hline Audit Opinion & 0.248 & 0498 \\
\hline
\end{tabular}

Table 11. Value Path Coefficients

\begin{tabular}{l|c|c|c|r|r}
\hline & $\begin{array}{c}\text { Original } \\
\text { Sample } \\
(\mathrm{O})\end{array}$ & $\begin{array}{c}\text { Sample } \\
\text { Mean } \\
(\mathrm{M})\end{array}$ & $\begin{array}{c}\text { Standard } \\
\text { Deviation } \\
(\text { STDEV) }\end{array}$ & $\begin{array}{c}\text { T Statistics }(\mid \\
\text { O / STDEV |) }\end{array}$ & P Values \\
\hline SPI -> Audit Opinion & 0.164 & 0.357 & 0.046 & 18.628 & 0.042 \\
\hline
\end{tabular}

From table 10 it can be concluded that the R-square value of 0.248 which can be interpreted as the BPK audit opinion variable which can be described by the variable application of the internal control system and the application of the principles of good government governance is $24.8 \%$, while $75.2 \%$ is explained by other constructs which were not the variables in this study.

Table 11 can be explained that the value of the original sample in this study is 0.164 , which means that the variable application of the internal control system affects BPK's audit opinion positively. The application of an internal control system in an organization is very important to get special attention from the leadership of the institution because in general, the weakness of the control system can lead to fraud that has an impact on BPK's audit findings. Internal control which is carried out in a measured and planned manner makes clarity in the structure of state financial accountability so that employees in this environment know the limits of work that can be done and cannot be done. Reward and punishment also need to be done so that the organization of the service apparatus will compete to show their best performance. 
The implementation of the internal control system was able to have an impact on BPK's audit opinion by $16.4 \%$, while the rest were other variables. The better the implementation of internal control in an Institution will have an impact on BPK's audit opinion.

The $t$ statistic value is 18,628 while the $t$ table is 1,980 with a value of $\alpha=5 \%$, so it can be said that the $t$ statistic is greater than the $t$ table $(18,628>1,980)$. Based on these data, it can be concluded that the implementation of the internal control system has a significant effect.

The conclusion of this study has similarities from the research of (Zufaldin and Maulina, 2017) which states that the audit opinion on the financial statements of the Lhokseumawe city government based on the internal control system still needs special handling because it is suspected that there are still many cases of abuse and abuse of authority. This means that the better the internal control, the better the audit opinion that will be obtained. (Irman and Suryati, 2017) show that the weakness of the internal control system affects the acceptance of audit opinion. The weaknesses of SPI are considered to harm the acceptance of Audit opinion, which means that the greater the SPI weaknesses found, the less likely the local government financial reports will accept the WTP opinion. The weaknesses of SPI include / not being carried out or inaccurate recording, the report preparation process is not following the provisions, the entity is late in submitting reports, the accounting information system and reporting are inadequate and the accounting and reporting information system is not supported by adequate human resources. (Winarto, 2020) in the research that has been conducted, obtained partial hypothesis testing results ( $\mathrm{t}$ test) of internal control, it can be concluded that partially internal control has a significant effect on audit opinion. This study is slightly different from the research of Safitri and (Darsono, 2015), concluding that the internal control system variable has a positive but insignificant effect at the 0.05 significance level on BPK's audit opinion in local governments.

The Effect of Internal Control System Implementation on Audit Opinion with the Application of Good Principles Government Governance as a Moderator Variable.

Table 12. Value Path Coefficients

\begin{tabular}{l|c|c|c|r|r}
\hline & $\begin{array}{c}\text { Original } \\
\text { Sample } \\
(\mathrm{O})\end{array}$ & $\begin{array}{c}\text { Sample } \\
\text { Mean } \\
(\mathrm{M})\end{array}$ & $\begin{array}{c}\text { Standard } \\
\text { Deviation } \\
(\text { STDEV) }\end{array}$ & $\begin{array}{c}\text { T Statistics }(\mid \\
\text { O / STDEV | }\end{array}$ & P Values \\
\hline SPI -> GGG-> Audit Opinion & 0.428 & 0.185 & 0.172 & 16.425 & 0.030 \\
\hline
\end{tabular}

Table 12 describes that the original sample value in this study was 0.428 , which means that there is a positive influence on the moderator variable of the application of the principles of good government governance on BPK's audit opinion. The moderator variable for the application of the principles of good government governance was able to moderate the variable of the application of the internal control system on audit opinion by $42.8 \%$, while $57.2 \%$ was influenced by other variables which were not the focus of this study.

Government governance that is transparent, accountable, and participatory has not been implemented properly, because it is still difficult for the public to access information about governance and the lack of participation of state managers in hearing the aspirations 
of the community. This is caused by inadequate human resources when the implementation of clean government governance based on the principles of good government governance is applied.

The value of $t$ count in this study amounted to 16,425 with a value of $\alpha=5 \%$. The $t$ table value in this study amounted to 1,980 . The value of $t$ is greater than the table $(16,425>$ 1,980 ), so it can be concluded that the moderator variable in the application of the principles of good government governance can become a moderator variable on the variable application of the internal control system which can have a significant impact on providing BPK audit opinion.

The results of this study are similar to research conducted by (Azlina and Amelia, 2014) which shows that the variable good governance significantly affects the performance of the Pelalawan regional government. (Agung and Mulyani, 2020) produce research that good governance has a positive and significant effect on the quality of financial reports, (Sari and Tamrin, 2020) find evidence that shows that there is a significant influence between the implementation of good government governance on the quality of financial statement information in the Agency. Regional Financial and Asset Manager Kendari City.

\section{CONCLUSION}

This research results in a conclusion that the better the implementation of an institution's internal control system will have an impact on the audit opinion that will be obtained. The application of the internal control system can positively and significantly influence BPK's audit opinion. Leaders in an organization/institution are very instrumental in implementing the internal control system. The moderator variable in the application of the principles of good government governance acts as a moderator variable, meaning that this variable can increase the impact of the variable application of the internal control system on the BPK audit opinion. The better the implementation of good governance, the better the audit opinion that will be obtained because there is control and the role of the community in the management of state finances.

Limitation and Future Research aims. This study explains the impact of the application of the internal control system and the application of the principles of good government governance. The results of this study are expected to contribute to the development of science and have an impact on good and clean governance so that the use of state finances is truly used for the prosperity of the people. However, this research is still far from perfect, there are still many shortcomings and weaknesses. Weaknesses and weaknesses in this study include the use of research variables that have not varied, the data from the questionnaire has a level of truth which is often questionable because the respondent's answer depends on the respondent's psychological factors, experience, education, and the level of the respondent's concern with the development of science.

Recommendations for research for researchers who take the same theme are expected to add a greater number of research variables. In addition to using questionnaire data which has many weaknesses and strengths, researchers should also observe a governance system. So that there is comparative data that can be used to conclude comprehensively. 


\section{REFERENCES}

Agung, Mochammad dan Mulyani, Sri. (2020). Pengaruh Good Governance dan Latar Belakang Profesi Kepala Daerah Terhadap Kualitas Laporan Keuangan dan Kinerja Pemerintah Daerah. Jurnal SIKAP (Sistem Informasi, Keuangan, Auditing Dan Perpajakan). 4. 142. 10.32897/JSIKAP.v4i2.352.

Antik Safitri, Niluh Ketut Shanti dan Darsono. (2015). Pengaruh Sistem Pengendalian Internal dan Temuan Kepatuhan Terhadap Opini Audit pada Pemerintah Daerah. Diponegoro Journal of Accounting Volume 5, Nomor 1 tahun 2015 halaman 1-12.

Atyanta, Ramya dan Rosidi. 2012. Analisis Opini BPK atas Laporan Keuangan Pemerintah Daerah (Studi Kasus pada Kabupaten X di Jawa Timur. Jurnal Ilmiah Mahasiswa FEB Universitas Brawijaya Vol. 1 No. 1.

Bandiyono, A. (2019). The Effect of Good Corporate Governance and Political Connection on Value Firm. Jurnal Akuntansi, 23(3), 333-348.

COSO. (2013). Internal Control_Integrated Framework: Executive Summary, Durham, North Carolina, May 2013.

Gzozali, Imam. (2014). Structural Equation Modeling. Metode Alternatif dengan Partial Least Squares (PLS). Semarang: Badan Penerbit Universitas Diponegoro.

Irman, Mimelientesa Irman dan Suryati. (2017). The influence of internal control system weaknesses, incompliance towards laws and regulations, the previous year's audit opinion and the age of the local government against acceptance of an audit opinion in the local goverment/riau province in 2011-2014. Jurnal KURS Vol. 2 No. 2.

Krina, Lalolo P. (2003). Indikator dan alat ukur Akuntabilitas, Transparansi dan Partisipasi. http//good governance: Bappenas.go.id/Informasi.Htm. Sekretaris Good Public Governance. Badan Perencanaan Pembangunan Nasional. Jakarta.

LAN dan BPKP. (2000). Akuntabilitas dan Good Governance, Modul Sosialisasi Sistem Akuntabilitas Kinerja Instansi Pemerintah. Jakrta: Penerbit LAN.

Nofianti, Leny. (2015). Public Sector Governance Pada Pemerintah Daerah. Pekanbaru.

Marwanto Harjowiryono. (2014). Modul Gambaran Umum Akuntansi Berbasis Akrual pada Program Percepatan Akuntabilitas Pemerintah Pusat. Jakarta: Kementerian Keuangan Republik Indonesia.

Peraturan Pemerintah Republik Indonesia Nomor 60 tahun (2008). Tentang Sistem Pengendalian Intern Pemerintah.

Peraturan Pemerintah Nomor 12 tahun (2019). Tentang Pengelolaan Keuangan Daerah.

Peraturan Menteri Dalam Negeri Republik Indonesia Nomor 19 tahun (2020). Tentang Pengukuran Indeks Pengelolaan Keuangan Daerah.

Rante, irwanto, Agustinus Salle dan Eisyan R. Marlissa. (2018). Analisis Terhadap Pemberian Opini Laporan Keuangan Pemerintah Daerah Kabupaten Pegunungan Bintang. Jurnal Kajian Ekonomi dan Keuangan Daerah Vol. 3 No. 2.

Raharjo, Agus. (2019). https://www.kupastuntas.co/2019/11/10/kpk-beberkan-25-provinsiterkorup-lampung-urutan-nomor-berapa-ya.

Sari, Ika Maya dan Nur Arvah Tamrin. (2017). Pengaruh Penerapan Good Government Governance dan Kompetensi Sumber Daya Manusia terhadap Kualitas Informasi Laporan Keuangan (studi pada Badan Pengelola Keuangan dan Aset Daerah Kota Kendari). Jurnal Akuntansi dan Keuangan Fakultas Ekonomi dan Bisnis, Universitas Halu Oleo Vol. 1 Nomor 1, page 106-121. 
Sedarmayanti. (2012). “APU, Good Governance "Kepemerintahan Yang Baik”, Bagian Kedua Edisi Revisi”. Bandung: CV. Mandar Maju.

Sekaran, Uma dan Roger Bougie. (2010). Research Methode For Business: A Skill Building Approach, Ed 5. John Wiley @ sons, New York.

Sulistoni, Gatot dan Hendriadi. (2004). Anggaran Tak Sampai. Nusa Tenggara Barat: Diterbitkan oleh Solidaritas Masyarakat Transparansi.

Transparancy International Indonesia (2020.

Undang-Undang Nomor 15 Tahun (2004). Tentang Pemeriksaan Pengelolaan dan Tanggung Jawab Keuangan Negara.

UNDP. (1997). Reconceptualising Governance: Discussion paper No. 2. The Principles of Good Governance.

Winarto, Herry. (2020). Pengaruh Pengendalian Internal dan Bukti Audit Terhadap Opini Audit (Studi Empiris di Kantor Akuntan Publik di Jakarta Timur). Jurnal Akuntansi dan Bisnis Krisnadwipayana. 7. 10.35137/JABK.v7i1.374.

Zufadlin, Yopi dan Rina Maulina. (2017). Opini Audit dan Sistem Pengendalian Intern (Studi Kasus di Pemerintah Kota Lhokseumawe yang mengalami Penurunan Opini Audit). Jurnal AKBIS: Media Riset Akuntansi dan Bisnis Volume 1 No 1 tahun 2017. 